\title{
Albanian Apparel Industry and Its Characteristics of Development
}

Armela Anamali 1

\author{
Alma Zisi 2 \\ Bitila Shosha ${ }^{3}$ \\ 1 University "Aleksander Moisiu" Durres, Lagj. Nr 1, Currila, Durres, Albania \\ 2University "Aleksander Moisiu" Durres, Lagj. Nr 1, Currila, Durres, Albania \\ 3University "Aleksander Moisiu" Durres, Lagj. Nr 1, Currila, Durres, Albania
}

\section{Doi:10.5901/ajis.2015.v4n3s1p585}

\section{Abstract}

For many years the phenomenon of offshore outsourcing has softened the economic problems of developing countries. The main industries that have developed thanks to outsourcing are labor-intensive industries and services. We recognize achievement indicators for developing countries like China, India, Philippines, etc. The reasons vary as the country's size, costs, level of education, the policies of the host country and many others. The set of these factors not only affects to the promotion of foreign investments, but also to the growth rate of an industry compared with others or international trade level for a particular category of goods / services. Albania has positive figures of development of offshore outsourcing particularly on apparel industry. The industry has been able to survive over two decades even though the economic and political changes. The modest data show little information about the characteristics of this industry, in terms of sector size, number of firms and their size, type of products, etc. The growth of the industry is focused only on positive net exports. The purpose of this paper is presenting a different picture of the industry, focusing on factors directly related to the development of apparel firms. Some of them are the functions (processes) they do, products, their experience, location, etc. This paper will help being familiar with the main characteristics of this industry as well as providing some important conclusions for its development in the future.

Keywords: Offshore outsourcing, global value chain, apparel industry, Albania.

\section{Introduction}

The term value chain is the set of processes from the product designing to the services offered after distribution. The organization of global chains is creating a system of successive economic links with other countries in the form of direct investment, joint ventures, licensing for production of products, subcontracting, etc.

Apparel value chains are buyer-driven chains (chains driven by international clients). International customers are retailers, manufacturers of well-known brands and well-known trade firm (Gereffi, 2002). These clients coordinate global clothing production between final markets and the production industries of developing countries. These kind of chains are typical in labor-intensive industries (such as agriculture-food industry, production of footwear, furniture, and similar), so very important for developing countries (UNIDO, 2005).

The barriers of a developing country, to be involved on any global value chain, are conditioned by unique knowledge and skills that cannot be learned by all. These barriers isolate firms that compete basing only on the activity price. In apparel value chains, activities with higher value added are design, marking and marketing. All these activities are largely based on the knowledge that large customers have (Kaplinsky, 2005).

In order to integrate in the apparel global value chains, a developing country should fulfill contract terms of foreign costumers in terms of quality, production capacity, the delivering time, compliance of different social and environmental standards, the distance and tastes among developing countries and the main markets where the product is exported.

It is equally important the improvement along the global value chain. The improvement of firms within global value chains brings growth the value added in domestic production and the country's economic growth. According to Kaplinsky et.al.(2002), the improvement along the global value chain may be:

- process improvement (the addition of new product lines, reducing defects, shortening the time of delivery, etc.);

- product improvement (quality improvement, introduction of a new product on time, etc.) 
- functional improvement (increase of value added through a combination of new activities within the firm or conducting activities that require greater skills and knowledge)

- cross-sectional improvement (transition to market segments where products are technically sophisticated and have a higher value added).

The apparel industry is one of the main industries for countries involved to export-oriented industrialization. According to Gereffi \& Memedovic (2003), the sector brings benefits to the economy of a country like:

- absorbing a large unskilled workforce,

- improving the country's trade balance,

- serving in the foundation of capital to invest in other industries, though itself requires low investment,

- increasing welfare and the domestic demand,

- enabling firms growth and access to local and regional markets with their brand,

- enabling the establishment of a western culture in doing business, etc.

After summarizing some of the main characteristics and implications of offshore outsourcing to developing countries (for the apparel global value chains), we make an analysis of the apparel industry in Albania and its involvement in global value chains.

\section{Apparel Industry in Albania}

The apparel industry is an early industry with a successful history of outsourcing even before 1990, with the state-owned enterprises. This industry was an important source of employment (about 45,000 employees), distributed in major cities like Tirana, Durres, Berat, Korce and Shkoder, etc.

After the regime change in 1990, the industry interrupts the activity. The main reasons for the cessation of activity were:

- The loss of domestic market share as a result of the competitiveness of imports;

- Unstudied privatization of state enterprises;

- $\quad$ Outdated production technology;

- Lack of funding and experience running private businesses.

The industry was involved in the privatization process in 1992-1993, with the investment of foreign firms. First apparel businesses settled in rented buildings of the former state-owned enterprises. The established firms were foreignowned or joint venture, mainly with italian, greek and german capital. The foundation of these entities was simulated by various factors where the most important were lower costs, a skilled workforce and the favorable geographical position.

In 2000, this industry turns the balance trade in positive values while in 2005 is listed as the main exporting industry in Albania. Positive figures of exports show a positive indicator regarding employment and the welfare improvement of the Albanians families. During 2007-2012 apparel exports had a steady growth rate. In 2012 this sectors accounted $29.2 \%$ of total exports (MEDTE, 2013).

Table 1: Exports for the period 2007-2012 (in million Euros).

\begin{tabular}{|c|l|c|c|c|c|c|c|}
\hline No. & Sector/Year & $\mathbf{2 0 0 7}$ & $\mathbf{2 0 0 8}$ & $\mathbf{2 0 0 9}$ & $\mathbf{2 0 1 0}$ & $\mathbf{2 0 1 1}$ & $\mathbf{2 0 1 2}$ \\
\hline $\mathbf{1}$ & Minerals and hydrocarbons & 121.3 & 166 & 156 & 324 & 418,15 & 521,602 \\
\hline $\mathbf{2}$ & Textile and footwear & 380 & 397 & 367 & 403,6 & 455,6 & 425 \\
\hline $\mathbf{3}$ & Construction Materials & 125.8 & 185.65 & 100.2 & 237.75 & 299.4 & 289 \\
\hline
\end{tabular}

Source: MEDTE (2013).

Firms in the apparel industry are price-taken, as European customers drive these types of chains. Albanian industry's two main priorities are geographical proximity and lower costs of labor compared to the region. One of the main problems in relationships with customers is the term of the contracts. The annually term of these contracts increases the degree of uncertainty about the future (ICS 2010). Apparel industry is mainly represented by the production of clothing and the manufacture in small amounts of textiles. Firms use in part the existing facilities, the cheap labor cost and employee experience.

The joint-ventures created in the apparel industry are mainly investments of italian, greek and german capital. These firms use modern production technology. According INSTAT in 2010, the number of employees in this industry was around 15 thousand employees. The leather and footwear industry is represented by internal processing companies 
that work with client's material. This industry has used the same opportunity as that of clothing (MEDTE, 2013).

After the agriculture sector, the clothing and textile industry is the second source of employment for women ( $90 \%$ of the employees are women). However, this sector has the lowest wages in the domestic economy (in the line of the minimum wage). The relationship between labor costs in Albania and Italy is 1 to 10 and compared with Greece is five times lower (NCMA 2013).

Apparel industry integration in the global value chains are backward integration (re-exportation of the product). According to the data around $64 \%$ of firms are specialized and produce more than one article. Only $36 \%$ are focused on the production of a single article. The clothes are mainly simple (underwear, shirts, pants, etc.).

Graph 1: The division of firms according the no. of articles they produce.

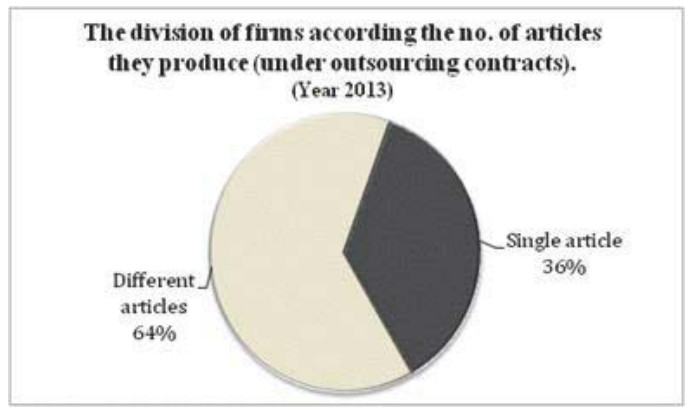

Source: AIDA_Fason (2014).

Using the data acceded from AIDA_Fason (2014) for a sample of 101 firms that operate in the apparel industry, we have calculated the statistics reflecting the firm size:

- The average number of employees in a firm is 104 employees.

- The average volume of annual contracts is approximately 575,532 Euros.

Firm's growth in apparel industry (translated into money volume of the contracts for 2013) has a positive effect on employment growth in the country. To verify the extent of the relationship between these variables, we analyzed their linear relationship using linear regression. From the statistical processing of data (AIDA_Fason, 2014), we obtained the following results:

Table 2: Model Summary

\begin{tabular}{|c|c|c|c|c|c|c|c|}
\hline \multicolumn{8}{|c|}{ Model Summary } \\
\hline \multirow{2}{*}{ Model } & \multirow{2}{*}{$\mathrm{R}$} & \multirow{2}{*}{ R Square } & \multirow{2}{*}{ Adjusted R Square } & \multirow{2}{*}{ Std. Error of the Estimate } & \multicolumn{3}{|c|}{ Change Statistics } \\
\hline & & & & & R Square Change & $\mathrm{F}$ & Sig. \\
\hline 1 & .528 & .278 & 271 & 92.74801 & .278 & 38.175 & 0.000 \\
\hline
\end{tabular}

Source: Authors Calculation using the data of AIDA_Fason (2014).

Table 3: The linear regression between the "Vol. Contract" \& "No. Employees".

\begin{tabular}{|c|c|c|c|c|c|}
\hline \multicolumn{6}{|c|}{ Coefficients } \\
\hline \multirow{2}{*}{ Model } & \multicolumn{2}{|c|}{ Unstandardized Coefficients } & Standardized Coefficients & \multirow{2}{*}{$\mathrm{t}$} & \multirow{2}{*}{ Sig. } \\
\hline & B & Std. Error & Beta & & \\
\hline Constant & 62.146 & 11.455 & & 5.425 & .000 \\
\hline$\sqrt[1]{\text { Vol. Contract }}$ & 8.134 & 1.316 & .528 & 6.179 & .000 \\
\hline
\end{tabular}

Source: Authors Calculation using the data of AIDA_Fason (2014). 
According the table above the econometric model is:

No. of Employees $=62.146+8.134$ Volume of Contract $+e$

The selection of the "Number of Employees" as the dependent variable and "Vol. Contracts" as the independent variable is based on the characteristics of apparel global value chains driven by customers (the principal) and the laborintensive industry. This model is statistically significant with a significance level 0.000 . The adjusted coefficient of determination turns out to be 0.271 , which means that $27.1 \%$ of the variation in the number of employees is explained by the variation in the volume of contracts. In the model are not included other factors for example investments in technology or the effects that incentives bring on industry development, etc.

For an increase of 100,000 Euro in the volume of contracts, the number of employees is expected to grow on average by about 8 individuals (or rather 8.134).

Using "stepwise method" in data processing, from the survey done in a sample of 60 apparel firms, we note that important determinants of their turnover are: new articles, the internal market, the number of clients, and additional activities.

The negative sign of the coefficient for the variable "new articles" tells us that the products' life cycle in the apparel industry has been shortened. Clients tend to acquire more new articles in smaller quantities, by reducing the turnover for each article produced and re-exported. It is well known that apparel firms in Albania produce for international clients using outsourcing contracts.

In addition to offshore outsourcing, an important target for domestic firms turns to be back the "domestic market" (Gereffi \& Memedovic, 2003). The same conclusion comes from the model, with significance level 0.001.

Although that the implementation of "additional activities" is positively related with the turnover growth, domestic firms remain in the lower link of the apparel value chain, doing activities with a low added value (Cut-Make-Trim). This can be justified by: international client's demand, nature of the industry and the socio-economic environment in Albania.

Table 4: Multiple regression.

\begin{tabular}{|c|c|c|c|c|c|c|c|}
\hline \multicolumn{8}{|c|}{ Coefficients (a) } \\
\hline \multirow{2}{*}{ Model } & \multicolumn{2}{|c|}{ Unstandardized Coefficients } & \multirow{2}{*}{\begin{tabular}{|c|} 
Standardized Coefficients \\
Beta
\end{tabular}} & \multirow{2}{*}{$\mathrm{t}$} & \multirow{2}{*}{ Sig. } & \multicolumn{2}{|c|}{ (95\%) B Confidence Interval } \\
\hline & $\mathrm{B}$ & Std. Error & & & & Lower Endpoint & Upper Endpoint \\
\hline (Constant) & 574393.89 & 163361.35 & & 3.516 & 0.001 & 247010.42 & 901777.36 \\
\hline New articles & -176990.8 & 37069.841 & -0.601 & -4.775 & 0 & -251280.44 & -102701.2 \\
\hline Domestic Market & 86594.403 & 23637.793 & 0.419 & 3.663 & 0.001 & 39223.208 & 133965.6 \\
\hline No. clients & 74480.534 & 32854.035 & 0.264 & 2.267 & 0.027 & 8639.576 & 140321.49 \\
\hline Additional activities & 59581.952 & 29220.019 & 0.247 & 2.039 & 0.046 & 1023.725 & 118140.18 \\
\hline
\end{tabular}

The apparel industry is a typical one, where large clients as retailers, branded manufacturers or branded stores realize activities with higher value added (core activities) and have a strong influence on custom manufacturers (Lee, 2006). Firms in developing countries have well-defined terms of the contracts on which work. Competition between firms in the country has imposed production at lower prices and increased customer flexibility in changing custom manufacturers.

National and local initiatives (sometimes in collaboration with international agencies) aim at improving specific skills and industry sectors, so that they can meet the requirements of international markets (Humphrey, 2004). Although apparel industry in the country is one of the main sectors that improves the trade balance, policies and initiatives to support the industry during these years have been sporadic and inconsistent

\section{Conclusion}

Despite the weight of industry (together with the footwear and leather section) in the country exports, its size is modest. The main reason is the engagement in low added value activities. Firms operating with low margins face increasing competition, keeping down prices and labor costs. During years ordered quantities for an item have been reduced, but at the same time increased the number of items and activities that firms exercise.

Until now firms have realized process upgrading (incorporation of more sophisticated technologies into production) and product upgrading upgrading (producing higher-value products), but not functional upgrading (moving to higher-value functions) within the apparel value chain. The main factors affecting their strategies are: the nature of the value chain (buyer-driven chain); buyer's needs and strategies; the development strategy of the government; the skills of the labor 
force; etc. The firm's turnover is dependent on buyer needs (number and type of articles), number of clients, domestic market and the activities they realize.

\section{References}

AIDA_Fason. (2014, June). Database - Apparel Industry. Albania, Tirana: Albania's Agency for Investment Development.

NCGM. 2013. Garment Focus. Tirana: National Chamber of Garment Manufacturers.

Gereffi, G. 2002. Outsourcing and Changing Patterns of International Competition in the Apparel Commodity Chain. In: Responding to Globalization: Societies, Groups, and Individuals, Boulder, Colorado, April 4-7, 2002.

Gereffi, G., \& Memedovic, O. 2003. The Global Apparel Value Chain: What Prospects for Upgrading by Developing Countries. Vienna, Austria: United Nations Industrial Development Organization (UNIDO).

Humphrey, J. 2004. Upgrading in global value chains. Geneva: International Labour Organization.

Kaplinsky, R. 2005. Globalization, Poverty and Inequality: Between a Rock and a Hard Place. Cambridge: Polity Press.

Kaplinsky, R., Morris, M., \& Readman, J. 2002. The Globalization of Product Markets and Immiserizing Growth. World Development, 30 (7), 1159-1177.

Lee, Y.-T. 2006. Buyer influence and supplier development in Buyer-Driven Global Supply Chain. PhD Thesis. Boston University

MEDTE 2013. Business and Investment Development Strategy 2014-2020. Tirana: Ministry of Economic Development, Trade and Entrepreneurship.

UNIDO 2005. Inserting Local Industries into Global Value Chains and Global Production Networks: Opportunities and Challenges for Upgrading. Vienna: United Nations Industrial Development Organization.

ICS. (2010). Rapid assessment of the impact of the global economic crisis on the apparel and footwear industry in Albania. Tiranë: Institute of Contemporary Studies. 